\title{
A structured literature review of corporate governance and performance research within an emerging country setting
}

\author{
Camelia I. Lungu ${ }^{1, a}$, Pompei Mititean ${ }^{2, a}$, Chirața Caraiani ${ }^{\mathrm{a}}$ and \\ Daniela Constantinescu ${ }^{\mathrm{a}}$
}

${ }^{a}$ Bucharest University of Economic Studies, Romania

\begin{abstract}
Research Question: The research proposition is to identify the particular interest of researchers, their work visibility and features, as well as the trend in the literature for corporate governance and corporate performance area of research from an emerging country perspective.

Motivation: The relationship between corporate governance and company performance is a widely debated topic in the literature. Regardless of the popularity of the topic addressed in the accounting literature, little research focused on carrying out a structured literature review in emerging countries.

Idea: The objective of this study is to debate on the relevance that the Romanian researchers has given to the study of the corporate governance and performance relationship.

Data: The database selected for the research is Web of Science, counting a total number of 114 papers included in the study.

Tools: A Structured Literature Review (SLR) is conducted, analysing the research published by the Romanian academics, referring to corporate governance and the performance of the companies.

Findings: The results illustrate multiple waves both in the interest of the researchers, as well as in the validation of their research. Most of the studies engage a quantitative methodology, focusing on the national companies' policies of corporate governance. Furthermore, the authors concentrate within three main universities in the country.

Contribution: This paper provides an approach to discover under-investigating topics and methods, thus being a starting point for researchers who will further study this subject. It may have direct implications especially in the academic environment of the European emerging countries.
\end{abstract}

${ }^{1}$ Corresponding author: Department of Accounting and Audit, Bucharest University of Economic Studies; Piața Romană, 6, room 1117; email address: camelia.lungu@cig.ase.ro

${ }^{2}$ Corresponding author: Accounting Doctoral School, Bucharest University of Economic Studies; Piața Romană, 6, room 1117; email address: mititeanpompei19@stud.ase.ro 
Keywords: Structured literature review, Corporate governance, Corporate performance, Emerging countries.

\section{JEL codes: M41, G34}

\section{Introduction}

Corporate governance and corporate financial performance have experienced great attention from the academic environment during the last years, being an important theme for debating. An extensive number of researchers (Chbib \& Page, 2020; Coletta \& Arruda de Souza Lima, 2020; Merendino, and Melville, 2019; Pham and Pham, 2020; Wijethilake \& Ekanayake, 2019; Liu, 2019; Song \& Kang, 2019; Kuo et al., 2020; Nashier \& Gupta, 2020) investigated the importance of corporate governance for the company's performance through examining the relationship using different measures. Based on these studies, the variables frequently chosen to measure the corporate governance mechanisms are: board size, CEO duality, gender diversity, ownership structure, ownership concentration, managers' revenue, corporate governance index. Related to various governance variables, the most used performance measures are: Tobin's $\mathrm{Q}$, return on equity (ROE), return on asset (ROA), return on investment (ROI) and economic value added (EVA).

Despite the numerous research papers published on this topic, only a limited number includes a structured literature review (SLR), such as E-Vahdati et al. (2019), AzilaGbettor et al. (2018), Oehmichen (2018), Gonzales-Bustos and Hernández-Lara (2016), Knut (2016), and Ng'eni (2015). There are two primarily reasons to conduct a SLR. First, it allows to identify and systematize the existing literature on a particular research topic, as well as to identify the interest that researchers have given to studying a specific area. Second, it provides new insights into the type of the researched relationships in the particular setting.

Advancing the importance of conducting a structured literature review (SLR), this paper focuses on corporate governance and performance relationship research and the interest on this filed for authors from a European emerging country. To study this relationship, a review of the publications indexed in the Web of Science database was carried out. Being a world-wide recognized database, it covers a large number of journals and international conferences, highly considered for academics' assessment in Eastern-Europe countries (Lungu et al., 2016; Albu \& Lungu, 2012; Glanzel, 2012; Kearney, 2012). By applying a SLR methodology, the main features of the Romanian research are identified. The three stages that must be followed to perform a SLR (Tranfield et al., 2003) are applied: (1) planning the review, (2) conducting the review and (3) reporting and dissemination. 
Considering the corpus of the Romanian literature, this paper approaches three research questions, relative to the corporate governance and the performance Romanian economic literature:

RQ1. How have the corporate governance and performance area of research developed in recent years within an emerging country setting?

$R Q 2$. The relevance of Romanian literature on the relationship between corporate governance and performance?

RQ3. Which are the main characteristics of the Romanian literature on the relationship between corporate governance and performance?

RQ3.1. Which are the most used theories in the Romanian authors' scientific research?

RQ3.2. Which are the most used research methodologies, methods and databases?

RQ3.3. Which are the most used variables measuring corporate governance and performance in the Romanian authors' scientific research

RQ3.4. How may the Romanian authors' papers be characterised in terms of general features?

The key characteristics and the results in this area of research are presented, using descriptive and frequency analysis, and discussed by reference to specifics of the international research on the subject. New insights, research questions, critical reflection and future research paths (Massaro et al., 2016) may be developed. Moreover, examining the structure and the characteristics of the papers published by Romanian authors, the use of this method replies to the need for systematization and identification of existing research in this field (Gonzales-Bustos \& Hernández-Lara, 2016). It contributes by providing an overview of the awareness and relevance in the field of governance. The results of this research provide a general overview on the different approaches taken by the Romanian authors when studying the relationship between the corporate governance and the performance.

This paper is organized as follows: Section 2 includes an overview of the corporate governance and performance studies, offering an international background. In Section 3, the key methodological aspects of the SRL method are explained, while in Section 4, the research findings are discussed. Section 5 is dedicated to the concluding remarks of this study.

\section{Literature review}

Over the past twelve years, subsequent to the biggest economic scandals, a lot of emphasis has been placed at international level, both on major reforms (Brown \& Caylor, 2009) and on the importance of studying the corporate governance (Tarraf, 2010). In general, corporate governance can be defined as the way the company 
management can influence its stakeholders (Shah et al., 2011). Corporate governance is the system by which companies are directed and controlled (Cadbury Report, 1992). OECD (2015) defines the corporate governance as a set of procedures and processes which helps an organisation to be controlled and directed. GonzalesBustos and Hernández-Lar (2016:34) consider that "the main goal of good governance in companies is to protect shareholders and other stakeholders from the managerial discretion". Corporate governance serves to create value in a company. For value creation, there is a need to implement corporate governance mechanisms. According to Cuervo (2002) the separation of owners and managers is necessary for maximising the value for the firm, to make it necessary to adopt the best governance mechanisms.

The relationship between corporate governance and financial performance was grounded on various analysis' frameworks designed on particular settings and criteria. Differences are also identified in the theories the researchers used, including the agency and signal theory (Tripathi, 2019; Bansal \& Thenmozhi, 2019; Sadeh \& Kacker, 2020). Adding to the specific settings, different research methods were applied. A number of authors have conducted statistical tests and regression analysis to describe the association between corporate governance and performance at international level. Detailing, part of them (Cincalova \& Hedija, 2020; Hussain \& Hadi, 2019) focused on the search for a correlation between different measures of corporate governance and performance, using Pearson's and Spearman's coefficients. Other authors (Nyaruri et al., 2019; Puni \& Anlesinya, 2020; Kyere \& Ausloos, 2020) used descriptive statistics and regression models to discuss on the particularities of the researched databases.

Most prior research analyse limited subsets of corporate governance characteristics in relation with various performance indicators. Accordingly, Chbib and Page (2020), Coletta and Arruda de Souza Lima (2020), Merendino, and Melville (2019), and Kalsie and Shrivastav (2016) examined the impact of the board of directors on the firm performance. The authors used Tobin's Q (TQ), Return on Assets (ROA), Return of Equity (ROE) as measurement of firm performance and the board size, and the board structure as measurement of corporate governance. By using a quantitative method (descriptive statistics and regression models), Chbib and Page (2020) and Merendino, and Melville (2019) found out that exist a high positive association between board size and TQ and an insignificant association between board size and ROA. The results of Coletta and Arruda de Souza Lima (2020) and Kalsie and Shrivastav (2016) indicate a significant positive relation between the board's structures and firm performance measured by using Tobin's Q and the market-to-book value ratio (MBVR). 
Pham and Pham (2020), Wijethilake and Ekanayake (2019), Liu (2019), Song and Kang (2019) and Tang (2017) used the governance variable measured as CEO duality to analyse the impact on financial performance. To measure the firm performance, Return on Assets (ROA), Earnings per share (EPS), Tobin's Q, Return on Equity (ROE) were used as independent variables. The results of Pham and Pham (2020) show that the CEO duality has a positive effect on firm performance in the growth stage of the life cycle and a negative impact in the maturing stage of the life cycle. Wijethilake and Ekanayake (2019) found out that the CEO duality has a negative impact when the CEO is having additional informal power, and a positive impact when board involvement is high. The results of Liu (2019) confirm that nonduality provides better performance than duality, while Song and Kang (2019) show a negative effect of CEO duality on firm performance.

Chijoke-Mgbame et al. (2020), Ouni et al. (2020) and Fernando et al. (2020) used the board gender diversity as a variable for corporate governance. Return on Asset (ROA) and Tobin's $Q$ were used to measure the firm performance. By using quantitative methods of research (descriptive statistics, correlation matrix, regression model), authors show that gender diversity has a positive impact on firm performance both in times of stability, but especially in times of crisis (Fernando et $a l ., 2020)$. Additionally, findings reveal that female board representation employs a positive and significant influence on firm financial performance (Chijoke-Mgbame et al., 2020, Ouni et al., 2020).

Other variables, such as ownership structure or ownership concentration were used by Kuo et al. (2020) and Nashier and Gupta (2020) to measure the corporate governance. They were related to performance measures such as Earnings before Tax and Interest (EBIT), Return on Asset (ROA), and Tobin's Q ratio. The regression models' and panel data models' results show that ownership concentration, ownership structure and the corporate governance index positively influence the performance of a company.

Moreover, Al-Gamrh et al. (2020), Kaur and Vij (2018), and Arora and Bodhanwala (2018) assessed a corporate governance index (CGI) by using various parameters for governance mechanisms, such as the board of directors' structure, the ownership structure, the market for corporate control and market competition. The results illustrate a positive impact of CGI on financial performance measured by Market-toBook Value of Equity (MVBE), Economic Value Added (EVA), ROA, EPS, and Tobin's Q ratio.

Regardless of the popularity of corporate governance (CG) concept addressed in the accounting literature in general, and its relationship with the financial performance, in particular, little research focused on carrying out a SLR (E-Vahdati et al., 2019, 
Azila-Gbettor et al., 2018, Oehmichen, 2018, Gonzales-Bustos \& Hernández-Lara, 2016). The main descriptive details of these studies are presented in Table 1.

Table 1. Research focused on carrying out a SLR in the corporate governance area

\begin{tabular}{|c|c|c|c|c|c|}
\hline Authors & $\begin{array}{c}\text { Factors } \\
\text { associated } \\
\text { with } \\
\text { corporate } \\
\text { governance }\end{array}$ & $\begin{array}{c}\text { No of } \\
\text { papers } \\
\text { analysed }\end{array}$ & $\begin{array}{c}\text { Time } \\
\text { period }\end{array}$ & $\begin{array}{c}\text { Data } \\
\text { sources }\end{array}$ & Keywords \\
\hline $\begin{array}{c}\text { E-Vahdati et } \\
\text { al. (2019) }\end{array}$ & Sustainability & 27 papers & N/A & $\begin{array}{c}\text { Scopus } \\
\text { database }\end{array}$ & $\begin{array}{c}\text { Leadership, } \\
\text { Sustainability, } \\
\text { Mission, } \\
\text { Corporate } \\
\text { governance, } \\
\text { Vision, } \\
\text { Framework }\end{array}$ \\
\hline $\begin{array}{l}\text { Azila-Gbettor } \\
\text { et al. (2018) }\end{array}$ & $\begin{array}{l}\text { Family firm } \\
\text { performance }\end{array}$ & $\begin{array}{c}159 \\
\text { papers }\end{array}$ & $\begin{array}{c}2000- \\
2016\end{array}$ & $\begin{array}{l}\text { Google } \\
\text { Scholar }\end{array}$ & $\begin{array}{l}\text { Performance, } \\
\text { Systematic } \\
\text { review, Family } \\
\text { firm, Corporate } \\
\text { governance } \\
\text { structures }\end{array}$ \\
\hline $\begin{array}{c}\text { Oehmichen } \\
\text { (2018) }\end{array}$ & $\begin{array}{c}\text { Corporate } \\
\text { performance }\end{array}$ & 84 papers & $\begin{array}{l}2002- \\
2016\end{array}$ & $\begin{array}{l}\text { Not } \\
\text { reported } \\
\text { by the } \\
\text { author }\end{array}$ & $\begin{array}{l}\text { Emerging } \\
\text { markets, Asia } \\
\text { Institutions, } \\
\text { Corporate } \\
\text { governance, } \\
\text { Ownership } \\
\text { structure, Boards } \\
\text { of directors }\end{array}$ \\
\hline $\begin{array}{l}\text { Gonzales- } \\
\text { Bustos and } \\
\text { Hernández- } \\
\text { Lara (2016) }\end{array}$ & Innovation & $\begin{array}{c}163 \\
\text { papers }\end{array}$ & $\begin{array}{l}1990- \\
2014\end{array}$ & $\begin{array}{l}\text { Web of } \\
\text { Science }\end{array}$ & $\begin{array}{c}\text { Corporate } \\
\text { Governance, } \\
\text { Ownership } \\
\text { Structure, Board } \\
\text { of Directors, } \\
\text { Innovation, } \\
\text { Systematic } \\
\text { Literature Review }\end{array}$ \\
\hline
\end{tabular}

E-Vahdati et al. (2019) conducted a SLR on corporate governance and sustainability integration showing that the integration of governance into sustainability is interpreted differently. Hence, sustainability frameworks may suggest a number of avenues for investors, policy makers and future market scenario which will increase the efficiency of companies. Azila-Gbettor et al. (2018) examined, based on a SLR, the extant of knowledge on corporate governance structures (CGS) and performance relation within family owned firms. With family businesses' corporate governance policies having a rapid grown, heterogeneous relation between measures of CGS and 
performance are revealed. Oehmichen (2018) conducted a SLR to show how corporate governance mechanisms in the Asian emerging markets context affect firm-level outcomes. Research on CG mechanisms could be extended to more than agency theory, recommending to add a stakeholder-oriented perspective. For a better understanding of the $\mathrm{CG}$ a detailed investigation of institutional contingency factors might be conducted. Gonzales-Bustos and Hernández-Lara (2016) conducted a SLR on the relationship between corporate governance and innovation. The main topics discussed refer to ownership concentration and the composition, and structure of boards of directors. They found a relatively low number of the studies published until 2004, with previous research showing no achieved consensus on the effect of CG mechanisms and innovation.

\section{Methodology and methods}

\subsection{Research method}

Regardless of the popularity of corporate governance concept addressed in the accounting literature in general, and its relationship with the financial performance, in particular, there is limited research focused on carrying out a structured literature review (Arora, 2015; Ng'eni, 2015; Knut, 2016; Azila-Gbettor, 2018). Various methods for conducting a literature review are identified as "systematic review, meta-analysis, rapid review, (traditional) literature review, narrative review, research synthesis, and SLR" (Massaro et al., 2016:769). The authors conclude that even if the traditional literature review is widely used in the accounting research, a more structured approach begun to be developed. Thus, the need for clear steps, following a logical structure, with increased validity and relevance supports the use of the SLR.

To answer the research questions, a Structured Literature Review (SLR) is conducted, analysing the research published by the Romanian academics, referring to corporate governance and the performance of the companies. According to Becheikh et al. (2006:645), the main purpose of this method is ,to identify key scientific contributions in a field and its results are often descriptively presented and discussed".

Tranfield et al. (2003) present three stages that must be followed to conduct a SLR. The first stage, planning the review, is detailed in three steps displayed in Figure 1. Performing a SLR means adopting a detailed, repeatable, scientific and transparent process, that minimizes bias through comprehensive literature research of published and unpublished studies (Moustaghfir, 2008). From the beginning, it is important to develop a review protocol. This protocol is a plan that may help to conduct the review. The plan contains information about the topics, the sample, the research topics, the strategy of choosing the relevant studies and some criteria that may help to include or exclude some papers. The second stage, conducting a review, is 
presented in seven steps that include: identifying the main purpose, identifying the keywords, selection of database, period and region, selection of studies, data extraction and data synthesis. The third stage, reporting and dissemination, is the last stage into a SLR that include two steps: the report and recommendations and the practically evidence.

\begin{tabular}{|c|c|c|}
\hline I. Planning the review & II. Conducting a review & $\begin{array}{l}\text { III. Reporting and } \\
\text { dissemination }\end{array}$ \\
\hline z & d & \\
\hline $\begin{array}{l}\text { (1) identification for } \\
\text { the need for a review } \\
\text { (2) preparation of a } \\
\text { proposal for a review } \\
\text { (3) development of a } \\
\text { review protocol }\end{array}$ & $\begin{array}{l}\text { (1) identifying the main } \\
\text { purpose of the research } \\
\text { (2) identifying search } \\
\text { keywords } \\
\text { (3) selection of the } \\
\text { search database } \\
\text { (4) establishing the } \\
\text { analysed period and } \\
\text { region } \\
\text { (5) selection of studies } \\
\text { (6) data extraction } \\
\text { (7) data synthesis }\end{array}$ & $\begin{array}{l}\text { (1) the report and } \\
\text { recommendations } \\
\text { (2) getting evidence } \\
\text { into practice }\end{array}$ \\
\hline
\end{tabular}

Figure 1. Steps in a Structured Literature Review (SLR) research methodology (Source: Tranfield et al., 2003: 214)

These steps need not to be chronologically followed, hence, this method has a great flexibility, allowing to the researcher to adding new criteria as they advance with the analysis of the articles (Caraiani et al., 2018: 539).

In order to carry out this research, for each accessed article, several specific aspects were followed, such as: keywords (how many times the two words appear in each article: governance and performance), the methodology that the researchers used it, the research methods used as well as the results obtained by the authors. Specific characteristics of each paper are also included in the analysis: number of citations, number of references, affiliation of the authors.

\subsection{Research database}

Following the planning stage of review, the purpose of this paper is identified. Designed as a Structured Literature Review (SLR) on the relationship between corporate governance and performance, the paper's main objective is to conduct a study on the main characteristics of the Romanian research on this subject, hence to debate on the relevance of the corporate governance literature in this specific setting. 
A comprehensive list of studies conducted by Romanian researchers are to be included in the research.

The detailed steps of the second stage in a SLR design are addressed further. Once the topic has been delimited, as the first step of conducting the review process (according to Tranfield et al., 2003), the data is extracted following the specific design of a SLR. Consequently, the second step is to identify the keywords. The choice of keywords is established from the beginning and relates to broad and generic topics on the concepts analysed, based on a very clear motivation. The keywords chosen for this study are: corporate governance, performance, firm performance and company performance. Azila-Gbettor et al. (2018) and Oehmichen (2018) also used similar keywords for their research. These chosen keywords allow to identify any study that has dealt with the studied relationship.

The third step is selecting the database. The database selected for the research is the online Web of Science Core Collection bibliographic and bibliometric database. This is a multidisciplinary platform, connecting regional and specialty data, allowing to track ideas across different disciplines over time. This world-wide recognised database is administrated by Clarivate analytics and covers a large number of journals and conferences highly considered for academics' evaluation at international and national levels. The search in this database has the purpose of finding papers with Romanian authors, having the research topic within the area of corporate governance and performance relationship. Both articles published in economic journals and papers presented at international conferences were considered.

The fourth step is to establish the analysed period. The searched span-time started at the beginning of the 2000s, when the first code of corporate governance addressed to the companies on Bucharest Stock Exchange was published in Romania and ended at the moment of the database construction, the late of 2019. The search function of the Web of Science Core Collection was used with reference to the topic of the papers that examines the titles, abstracts and the keywords of the articles. The search initially generated 340 publications (Table 2).

Table 2. The breakdown of keywords' combinations and number of papers

\begin{tabular}{lcc}
\hline Keywords' combination & $\begin{array}{c}\text { Papers initially } \\
\text { selected }\end{array}$ & $\begin{array}{c}\text { Papers } \\
\text { considered in } \\
\text { the final } \\
\text { database }\end{array}$ \\
\hline Corporate Governance and firm performance & 65 & 38 \\
Corporate Governance and company performance & 111 & 53 \\
Corporate Governance and performance & 164 & 23 \\
\hline \multicolumn{1}{c}{ Total } & $\mathbf{3 4 0}$ & $\mathbf{1 1 4}$ \\
\hline
\end{tabular}

Vol. 19, No. 4 
The fifth step is to download information about the articles that resulted from the search. Based on the information provided by the database, information about the authors, year of publication, keywords used, article summary, number of citations were downloaded. Next, the list was processed by sorting, comparing, analysing. After removing the duplicates and analysing the abstracts of these articles, the database was narrowed to 164 papers, published by the Romanian authors over the 2006-2019 period on the topics covering corporate governance and corporate performance.

After establishing this level of the database, the full content of each article was searched in order to apply the structured analysis, according to the sixth and sevenths steps of conducting the review (Tranfield et al., 2003). Thus, some articles were downloaded directly from the journal's or conference's website, as they were of open access type. Others were found on Google Scholar, or on Research Gate, while, for the restricted access articles, emails were sent to authors or to the conference/journals. Because of the restricted access to a number of publications, only 114 papers (published between 2010 and 2019) were included for a detailed analysis in the final database. By conducting a content analysis of the papers' abstract and keywords, the elimination process and the creation of the final database, the keywords selected for this structured literature review were combined threeways, as presented in Table 2. The final number of 114 articles, considered for the in-depts analysis, was downloaded in their complete format.

\section{Results}

\subsection{The development of corporate governance and performance area of research within an emerging country setting}

The descriptive and frequency analysis of Romanian literature on relationship between corporate governance and performance is used to identify the development process of the literature. The structure and the trend of the 114 articles included in the database are presented in Figure 2 with a breakdown on the type of publications (articles published in journals and papers presented at conferences). While at the beginning of the researched period the papers published in conference proceedings surpassed the number of articles published in journals, the balance reversed starting with 2016. For both conferences and journals the pics were registered in 2015. The current situation shows a significant increase in the number of articles published in journals. 


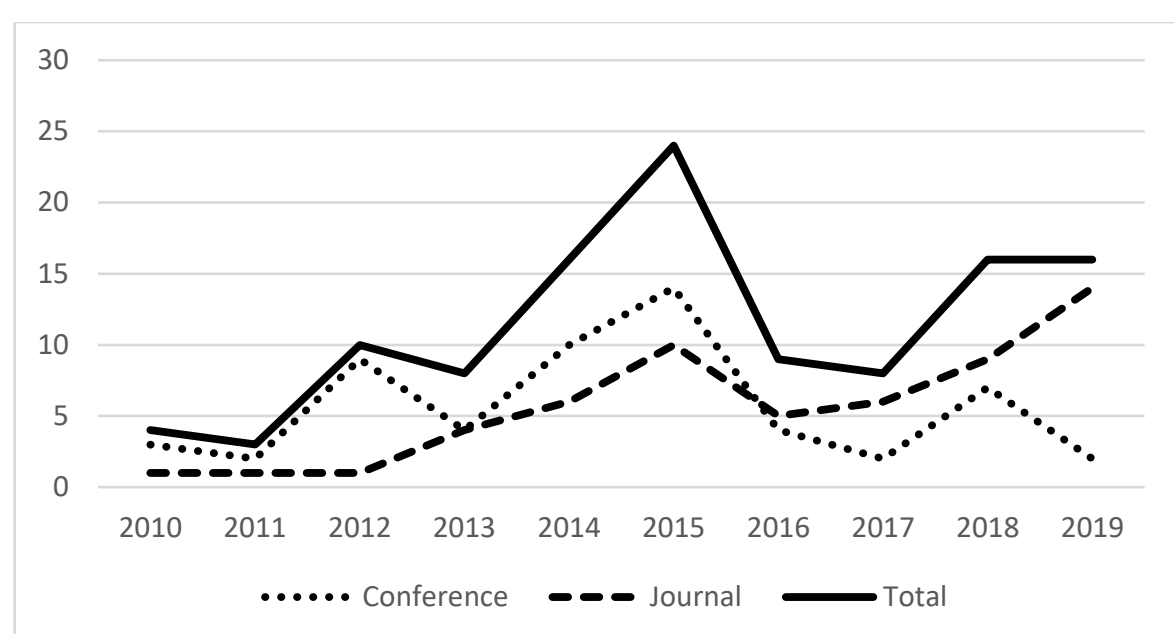

Figure 2. Evolution of the number of papers per year and type of publication

Further details are included in Table 3. Considering the type of publication, findings show that, during 2010-2019, out of the 114 articles included in this analysis, an equal number of 57 articles were presented at conferences and published in internationally recognized journals. However, the evolution along the years is significantly different.

Table 3. Number of papers published in conference proceedings or journals

\begin{tabular}{|c|c|c|c|c|c|c|c|c|c|c|c|}
\hline Yea & '10 & 11 & 612 & 13 & ' 14 & 15 & '16 & 617 & 618 & 619 & Total \\
\hline \multirow[t]{2}{*}{ Conference } & 3 & 2 & 9 & 4 & 10 & 14 & 4 & 2 & 7 & 2 & 57 \\
\hline & $5 \%$ & $4 \%$ & $16 \%$ & $7 \%$ & $18 \%$ & $25 \%$ & $7 \%$ & $4 \%$ & $12 \%$ & $4 \%$ & $100 \%$ \\
\hline \multirow[t]{2}{*}{ Journal } & 1 & 1 & 1 & 4 & 6 & 10 & 5 & 6 & 9 & 14 & 57 \\
\hline & $2 \%$ & $2 \%$ & $2 \%$ & $7 \%$ & $11 \%$ & $18 \%$ & $9 \%$ & $11 \%$ & $16 \%$ & $25 \%$ & $100 \%$ \\
\hline \multirow[t]{2}{*}{ Total } & 4 & 3 & 10 & 8 & 16 & 24 & 9 & 8 & 16 & 16 & 114 \\
\hline & $4 \%$ & $3 \%$ & $9 \%$ & $7 \%$ & $14 \%$ & $21 \%$ & $8 \%$ & $7 \%$ & $14 \%$ & $14 \%$ & $100 \%$ \\
\hline
\end{tabular}

Table 3 shows that the number of papers conducted by Romanian authors on the corporate governance and performance topic in the early stages of the studied period was limited. In the first two years of the research period, only 2 articles were published in journals and 5 papers were included in conference proceedings. Starting with 2012, the evolution began to change, resulting in an overall increasing trend until 2015, with a small decrease in 2013. An abrupt decrease in 2016 was followed by a second wave of increasing interest in this research area for the Romanian academics, with a change in the dissemination instruments. Journals are preferred to conferences. The highest number of papers registers in 2019 for journals and in 2015 for conference proceedings, with $24 \%$ of total publications in each category. Thus, 
an oscillating and inconsistent evolution may be noticed in the interest of Romanian researchers for the corporate governance and performance topic.

\subsection{The relevance of corporate governance and performance topic addressed by Romanian researchers}

Using the frequency analysis technique, the characteristics of authors' affiliation is first considered in examining the relevance of research. Table 4 illustrates a breakdown analysis including various characteristics of the papers, such as authors' affiliation, presented in terms of number of papers and number of authors, and the interest of Romanian universities' researchers in the corporate governance and performance area of research.

Table 4. Breakdown analysis considering authors' affiliation

\begin{tabular}{lrr}
\hline & Number & Frequency \\
\hline A. Romanian versus international affiliation & & \\
Total number of papers, of which: & $\mathbf{1 1 4}$ & $\mathbf{1 0 0 \%}$ \\
$\quad \begin{array}{l}\text { Papers with the first author affiliated to Romanian } \\
\text { universities }\end{array}$ & 109 & $96 \%$ \\
$\quad \begin{array}{l}\text { Papers with the first author affiliated to international } \\
\text { universities }\end{array}$ & 101 & $4 \%$ \\
$\quad$ Papers with Romanian authors only & 13 & $\mathbf{8 9 \%}$ \\
$\quad$ Papers with international affiliated authors & $\mathbf{2 6 9}$ & $\mathbf{1 0 0 \%}$ \\
Total number of authors, of which: & 246 & $91 \%$ \\
$\quad$ Authors affiliated to Romanian universities & 23 & $9 \%$ \\
$\quad$ Authors affiliated to international universities & $\mathbf{2 . 3 6}$ & \\
The average number of authors per article & & \\
& & \\
B. Top 3 Romanian Universities* & 46 & $42 \%$ \\
Bucharest University of Economics Studies & 22 & $20 \%$ \\
Babeș-Boyai University of Cluj-Napoca & 10 & $9 \%$ \\
Alexandru Ioan Cuza University of Iași & & \\
\hline
\end{tabular}

*Papers with the first author affiliated to Romanian universities are included here.

Out of the 114 published papers, 109 articles (96\%) have the first author affiliated to a Romanian university, while 101 articles (89\%) have only Romanian authors. In 13 articles the Romanian authors collaborated with international authors, with 5 articles having an international researcher as first author. Detailing, most of the papers (46 papers representing 42\%) are conducted by researchers affiliated to the Bucharest University of Economic Studies Researchers from other two Romanian universities, Babeș-Bolyai University of Cluj-Napoca (with 22 papers representing 20\%) and Alexandru Ioan Cuza University of Iași (10 papers representing 9\%), have been interested in conducting studies in corporate governance and performance area. 
The total number of authors conducting research in this area includes 269 researchers, of which $246(91 \%)$ are affiliated to Romanian universities and $23(9 \%)$ are affiliated to international universities form 10 different countries. Most of the international universities are from China and France, with three universities each, and Iraq, Poland and Switzerland, with two universities each.

Next, the relevance of research is illustrated through the analysis of the number of citations returned by Clarivate analytics database in the journal citation report. Table 5 illustrates the number and the percentage of citations for the articles published by Romanian authors in the area of corporate governance and performance. The total number of citations is 238 for all the articles of the Romanian authors published between 2010 and 2019. Considering the last 10 years of data, the average citation score registers a value of 23.8 citations/year and of 2.1 citations/paper (238 citations for a total of 114 papers). The maximum of citations is represented by 2017 year when count a number of 42 citations and the minimum is represented by 2019 with a number of 7 citations. It can be seen that most citations belong to articles published in journals, with a number of 189 citations for the analysed period out of a total of 238 citations.

Table 5. Breakdown analysis considering the citations by type of publication

\begin{tabular}{|c|c|c|c|c|c|c|c|c|c|c|c|}
\hline Type & ‘ 10 & '11 & 612 & ' 13 & ' 14 & 615 & 16 & ' 17 & 18 & '19 & Total \\
\hline \multirow[t]{2}{*}{ Conference } & 0 & 0 & 18 & 9 & 11 & 8 & 1 & 0 & 2 & 0 & 49 \\
\hline & $0 \%$ & $0 \%$ & $8 \%$ & $4 \%$ & $5 \%$ & $3 \%$ & $0 \%$ & $0 \%$ & $1 \%$ & $0 \%$ & $21 \%$ \\
\hline \multirow[t]{2}{*}{ Journal } & 17 & 38 & 1 & 2 & 26 & 21 & 19 & 42 & 16 & 7 & 189 \\
\hline & $7 \%$ & $16 \%$ & $0 \%$ & $1 \%$ & $11 \%$ & $9 \%$ & $8 \%$ & $18 \%$ & $7 \%$ & $3 \%$ & $79 \%$ \\
\hline \multirow[t]{2}{*}{ Total } & 17 & 38 & 19 & 11 & 37 & 29 & 20 & 42 & 18 & 7 & 238 \\
\hline & $7 \%$ & $16 \%$ & $8 \%$ & $5 \%$ & $16 \%$ & $12 \%$ & $8 \%$ & $18 \%$ & $8 \%$ & $3 \%$ & $100 \%$ \\
\hline
\end{tabular}

\subsection{Meta-analysis of Romanian literature on the relationship between corporate governance and performance}

The third research question addressed in this paper is responded by using a metaanalysis investigation to understand the main characteristics of the Romanian literature on the relationship between corporate governance and performance. Five different criteria are used to characterize the research articles. Details about the results observed for each criterion are presented further. Explanations and interpretations, related to the chosen criteria, accompany the quantitative results.

\section{A. Theories}

Table 6 presents the top fourth most used theories characterising the Romanian authors' research in corporate governance and performance. The most used theory is 
the Agency theory, identified in 21 articles (18.4\% of the total), followed by the Stakeholder Theory, in 8 articles (7\% of the total). Other two theories, however less used by Romanian researchers, are the stewardship theory and the attribution theory.

Table 6. Top four most used theories in Romanian research

\begin{tabular}{lr}
\hline Theory & $\begin{array}{r}\text { No. of articles } \\
\text { (Frequency) }\end{array}$ \\
\hline The Agency theory & $21(18.4 \%)$ \\
The Stakeholder theory & $8(7.0 \%)$ \\
The Stewardship theory & $4(3.5 \%)$ \\
The Attribution theory & $2(1.8 \%)$ \\
\hline
\end{tabular}

Ienciu et al. (2012) study the relationship between corporate governance and environmental reporting, based on the Agency Theory. By using a quantitative method (descriptive statistics and regression model) the authors identify that the corporate governance contributes to explaining the variation in environmental information disclosure and a good corporate governance increasing transparency regarding the environmental aspects. Based on Stakeholder Theory, Dinca et al. (2019) analyse the environmental information disclosure with the purpose of identifying possible correlations with the evolution of a number of corporate economic and financial relevant measures. Using a quantitative method, authors state that the size and the performance of the companies have a positive impact on the environmental information disclosure.

\section{B. Research methodology and methods}

The research methodology used by Romanian researchers in corporate governance area is mostly quantitative (78\%, with 89 papers out of 114). The majority of the papers use descriptive statistics, quantifiable-answered questionnaires, regression models or correlation matrix. The qualitative research methodology covers $18 \%$ of the papers (20 out of 114). Results show that five papers didn't present any research methodology (Table 7).

Table 7. Research methodology and methods used in Romanian research

\begin{tabular}{lcc}
\hline & No. of articles & Frequency \\
\hline Research methodologies & 89 & \\
Quantitative & 54 & $78 \%$ \\
Regression/Econometric analysis & 17 & $47 \%$ \\
Descriptive Statistics & 12 & $15 \%$ \\
Descriptive Analysis & 6 & $11 \%$ \\
Content Analysis & 20 & $5 \%$ \\
Qualitative & 6 & $18 \%$ \\
Questionnaires & 3 & $5 \%$ \\
Reports Analysis & & $3 \%$ \\
\hline
\end{tabular}




\begin{tabular}{lcc}
\hline & No. of articles & Frequency \\
\hline Literature Review & 2 & $2 \%$ \\
Historical Analysis & 2 & $2 \%$ \\
Interview & 2 & $2 \%$ \\
Other specified methods & 5 & $4 \%$ \\
No research methodology & 5 & $4 \%$ \\
\hline Total papers & $\mathbf{1 1 4}$ & $\mathbf{1 0 0 \%}$ \\
\hline
\end{tabular}

Details regarding the research methods show that, despite the variety of methods used by the Romanian authors, the most common one is the regression/econometric analysis, applied in $47 \%$ out of the papers analysed for this study. Exemplifying, Hațegan and Curea-Pitorac (2017) use logistic regression on profitable companies listed at Bucharest Stock Exchange, during the 2011-2016 period. Studying the relationship between the charitable contributions, performance indicators, and market value of Romanian listed companies, authors disclose positive correlations between these variables for the Romanian listed companies. The descriptive statistics (with 15\%) and descriptive analysis (with 11\%) are the next two methods used by Romanian researchers. Achim et al. (2016) study the relationship between corporate governance and performance for the companies listed on the Bucharest Stock Exchange for the 2001-2011 period, using descriptive statistics. Incorporating a corporate governance index to measure the quality of corporate governance, authors obtain a positive correlation with the market value of companies, measured by Tobin's Q.

Content analysis and questionnaires are employed in other 10 papers. All the other methods utilized by the authors are not significantly represented. Within 5 of the articles the authors specified other methods, such as case study, comparative analysis, deductive approach, inductive analysis, and non-participating observation.

\section{Sample's characteristics and the most used databases}

The research methods and methodology analysis generated an in-depth analysis of the characteristics of the population addressed in the Romanian research aiming at the relationship between the corporate governance and performance, correlated with the research method employed. Secondary analysis on the most used databases completed this criterion.

Table 8 illustrates that the studies of Romanian researchers are largely focused on the analysis of companies. For example, Gherghina and Vintilă (2015) study the relationship between the internal corporate governance mechanisms (board size, independence, gender diversity, CEO duality), CEO characteristics and firm performance. The study is conducted on hand-collected data, including 334 statistical observations, for the 2007 - 2011 period, analysing the reports of 68 companies listed on Bucharest Stock Exchange. Using panel data regression models, 
the study finds mixed effects of governance mechanisms as CEO duality or board size on company's performance when cross-sectional effects are considered as compared with no fixed-effects data.

Table 8. Samples' characteristics associated with the research method

\begin{tabular}{|c|c|c|c|}
\hline Studied population & Research method & Total articles & $\begin{array}{c}\text { Articles } \\
\text { referring } \\
\text { to Romanian } \\
\text { data }\end{array}$ \\
\hline \multirow[t]{11}{*}{ Companies } & & 86 & 45 \\
\hline & Regression/Econometric analysis & 52 & 20 \\
\hline & Descriptive statistics & 16 & 10 \\
\hline & Content analysis & 5 & 5 \\
\hline & Questionnaires & 4 & 2 \\
\hline & Descriptive Analysis & 3 & 2 \\
\hline & Reports Analysis & 2 & 2 \\
\hline & Case study & 1 & 1 \\
\hline & Interview & 1 & 1 \\
\hline & No specified methods & 1 & 1 \\
\hline & Non-participating observation & 1 & 1 \\
\hline \multirow[t]{3}{*}{ Articles } & & 2 & 1 \\
\hline & Deductive approach & 1 & 1 \\
\hline & Reports Analysis & 1 & 0 \\
\hline \multirow[t]{3}{*}{ Countries } & & 2 & 0 \\
\hline & Comparative analysis & 1 & 0 \\
\hline & Regression/Econometric analysis & 1 & 0 \\
\hline \multirow[t]{5}{*}{ Individual respondents } & & 5 & 3 \\
\hline & Questionnaires & 2 & 1 \\
\hline & Interview & 1 & 1 \\
\hline & No specified methods & 1 & 1 \\
\hline & Descriptive Analysis & 1 & 0 \\
\hline Not Specified & & 19 & 3 \\
\hline Total & & 114 & 52 \\
\hline
\end{tabular}

Other studies focus on the analysis of articles, countries, and individual respondents. Using a questionnaire of 32 closed-ended questions, with multiple choice answer options, Popescu and Popescu (2019) analyse the relationship between corporate social responsibility, intellectual capital and performance, providing valuable insights and relevant evidence from a Romanian business environment. Based on a number of 642 valid answers obtained from representatives of the occupied population in Romania, the results reveal a high importance attributed by employers 
and employees in the Romanian business environment, to the relationships between corporate social responsibility, intellectual capital and corporate performance.

Advancing on the geographical location of the population investigated by Romanian authors, it may be noticed (Table 9) that overall, almost half of the studies disclose the use of Romanian data (48 articles representing 43\%). This suggests that the main interest of the Romanian researchers in studying the relationship between corporate governance and corporate performance is related to the Romanian companies. The low level of international database research conducted by the Romanian authors ( 20 articles representing 17\%) needs to be analysed in the context of the high percentage $(40 \%)$ of not disclosed information on the database used for the study. A limited number of papers studied data extracted from worldwide databases such as Thomson Reuters, ORBIS, Bloomberg, and Eurostat.

Table 9. Top 10 most used databases

\begin{tabular}{lccl}
\hline \multicolumn{1}{c}{ Database } & $\begin{array}{c}\text { No. of } \\
\text { articles }\end{array}$ & Frequency & Type of the database \\
\hline $\begin{array}{l}\text { Bucharest Stock } \\
\text { Exchange }\end{array}$ & 31 & $27 \%$ & $\begin{array}{l}\text { Romanian Database } \\
\text { Rompanian Database }\end{array}$ \\
$\begin{array}{l}\text { National Bank of } \\
\text { Romania }\end{array}$ & 12 & $11 \%$ & Romanian Database \\
Ministry of Public & 3 & $3 \%$ & \\
Finance & 2 & $2 \%$ & Romanian Database \\
Thomson Reuters & & & \\
Database & 3 & $7 \%$ & International Database \\
London Stock Exchange & 3 & $3 \%$ & International Database \\
ORBIS Database & 2 & $3 \%$ & International Database \\
Bloomberg & 2 & $2 \%$ & International Database \\
Chinese stock market & 2 & $2 \%$ & International Database \\
Eurostat & 46 & $40 \%$ & International Database \\
Others & $\mathbf{1 1 4}$ & $\mathbf{1 0 0 \%}$ & \\
\hline Total & & & \\
\hline
\end{tabular}

Illustrating the research based on Romanian database, the study of Ionașcu et al. (2018) is taken as example. The authors collected 343 firm-year observations on both the Premium and Standard tiers of Bucharest Stock Exchange during 2012-2016. Studying the association between gender diversity on corporate boards and firm performance for a European emerging market, the research uses regression analysis and confirms previous concerns related to the endogeneity of gender diversity variables in firm performance. The authors show that, on average, diversity has no significant impact on firm-performance. A research using an international database, ORBIS, is conducted by Horobet et al. (2019). The relationship between ownership concentration and corporate performance in the manufacturing sector in the 
European Union is investigated by using a detailed and methodical statistical analysis on 2,512 companies listed on various European Stock Exchanges. The results illustrate a positive impact between ownership concentration and corporate performance in the case of Western companies and a negative impact for Easternbased companies.

\section{Keywords analysis and the related metrics used in Romanian research}

The frequency of the two underlying keywords chosen for this study (governance and performance) is presented in Table 10. The keyword governance counts a total of 4,907 occurrences within the 114 articles studied, with an average of 43.04 occurrences/article, a minimum of 1 occurrence and a maximum of 211 occurrences in a single article. The keyword performance counts a total of 4,931 occurrences within the 114 articles studied, with an average of 43.25 per article, a minimum of 2 and a maximum of 302 occurrences in a single article.

Table 10. Descriptives of the governance and performance keywords

\begin{tabular}{lcc}
\hline Type & Governance & Performance \\
\hline Total count & 4,907 & 4,931 \\
Average frequency of the keywords & 43.04 & 43.25 \\
Min & 1 & 2 \\
Max & 211 & 302 \\
\hline
\end{tabular}

Extending the keyword analysis, the results move forward with the statistics of the metrics most used by the Romanian authors to measure the corporate governance, and corporate performance (Table 11).

Table 11. Top 7 corporate governance and performance related metrics

\begin{tabular}{lclc}
\hline Corporate Governance & No. of articles & Corporate Performance & No. of articles \\
\hline Board independence & 16 & Return on Assets & 35 \\
CG index & 13 & Return on Equity & 31 \\
Board size & 13 & Tobin's Q ratio & 11 \\
Board gender diversity & 10 & Total assets & 7 \\
CEO-chair duality & 9 & Market to book value & 5 \\
Ownership structure & 8 & Earnings per share & 4 \\
Audit committee & 6 & Altman score & 3 \\
\hline
\end{tabular}

After filtering and sorting the indicators used by the Romanian authors to measure of corporate governance and corporate performance, the most common variables chosen by the authors of the studied articles are the board independence, the corporate governance index/score and the board size. For quantifying the corporate performance, the most common metrics used by the authors are Return on Assets, 
Return on Equity, and Tobin's $Q$ ratio. These results are similar with the studies conducted at international level, by Bhagat \& Bolton (2008), Jackling and Johl (2009) or Masulis et al. (2012).

\section{E. Length and quality of Romanian research}

For the length characteristic of the papers, the number of pages was considered. The quality of the papers is addressed by extracting from the Clarivate analytics database, the number of references and the number of citations of each paper.

The total number of the analysed articles, including the appendix, amounts to 1,799 pages, with an average number of 15.78 pages per paper (Table 12). The descriptive statistics indicate the shortest paper, having 3 pages are published in a journal that starting with the year 2013, was removed from the Web of Science database. The most extensive one, with 79 pages is a paper published in December 2019, in the Journal of Risk and Financial Management.

Table 12. Number of pages, references, and citations

\begin{tabular}{lc}
\hline Characteristics & Descriptive statistics \\
\hline Total number of pages & 1,799 \\
Average pages per paper & 15.78 \\
Min of pages of one paper & 3 \\
Max of pages of one paper & 79 \\
Total number of references & 4,580 \\
Average number of references per paper & 40.18 \\
Min of references & 6 \\
Max of references & 140 \\
Total number of citations & 238 \\
Average number of citations per paper & 2.09 \\
Min of citations & 0 \\
Max of citations & 38 \\
\hline
\end{tabular}

Analysing the number of papers' references, a total of 4,580 references are counted for the 114 articles, with an average of 40.18 references/paper. The minimum number of references used in a paper is 6 . There are 4 papers in this category, out of which 3 are single authored papers, and one has two authors, all affiliated to Romanian universities. All four are published in conferences' proceedings. Popescu and Popescu (2019) the paper with the highest number of references, having also the highest number of pages, is published in Journal of Risk and Financial Management.

Out of the total of 114 articles included in this analysis having a total of 238 citations, 137 citations belong to the top 10 most cited articles, while 90 papers have no more than 2 citations. The top ten most cited articles published by Romanian authors in the field of corporate governance and performance for the analysed period are presented in Table 13. 
Table 13. Top 10 most cited papers

\begin{tabular}{|c|c|c|c|c|c|}
\hline No. & Title & Authors & $\begin{array}{c}\text { Publication } \\
\text { year }\end{array}$ & $\begin{array}{c}\text { No of } \\
\text { citations }\end{array}$ & $\begin{array}{l}\text { Average } \\
\text { citations } \\
\text { per year }\end{array}$ \\
\hline 1 & $\begin{array}{l}\text { Gender and management on } \\
\text { Spanish SMEs: an empirical } \\
\text { analysis }\end{array}$ & $\begin{array}{l}\text { Minguez } \\
\text {-Vera } \\
\text { and } \\
\text { Martin }\end{array}$ & 2011 & 38 & 4.22 \\
\hline 2 & $\begin{array}{l}\text { Testing the Correlations } \\
\text { between Corporate Giving, } \\
\text { Performance and Company } \\
\text { Value }\end{array}$ & $\begin{array}{l}\text { Hategan } \\
\text { and } \\
\text { Curea- } \\
\text { Pitorac }\end{array}$ & 2017 & 17 & 5.67 \\
\hline 3 & $\begin{array}{l}\text { Commercial activity's } \\
\text { contribution to sustainable } \\
\text { development by social } \\
\text { responsibility actions: a } \\
\text { vision of SMEs }\end{array}$ & $\begin{array}{l}\text { Zaharia } \\
\text { et al. }\end{array}$ & 2010 & 17 & 1.70 \\
\hline 4 & $\begin{array}{l}\text { Environmental Reporting } \\
\text { and Good Practice of } \\
\text { Corporate Governance: } \\
\text { Petroleum Industry Case } \\
\text { Study }\end{array}$ & $\begin{array}{c}\text { Ienciu et } \\
\text { al. }\end{array}$ & 2012 & 12 & 1.50 \\
\hline 5 & $\begin{array}{l}\text { Exploring the impact of } \\
\text { corporate social } \\
\text { responsibility policies on } \\
\text { firm value: the case of listed } \\
\text { companies in Romania }\end{array}$ & $\begin{array}{l}\text { Gherghi } \\
\text { na and } \\
\text { Vintilă }\end{array}$ & 2016 & 10 & 2.50 \\
\hline 6 & $\begin{array}{l}\text { Multinationals as Vectors of } \\
\text { Corporate Governance } \\
\text { Improvement in Emerging } \\
\text { Economies in Eastern } \\
\text { Europe: A Case Study }\end{array}$ & $\begin{array}{l}\text { Albu et } \\
\text { al. }\end{array}$ & 2014 & 10 & 1.67 \\
\hline 7 & $\begin{array}{l}\text { Corporate governance and } \\
\text { business performance: } \\
\text { evidence for the Romanian } \\
\text { economy }\end{array}$ & $\begin{array}{l}\text { Achim } \\
\text { et al. }\end{array}$ & 2016 & 9 & 2.25 \\
\hline 8 & $\begin{array}{l}\text { Women on Boards and } \\
\text { Financial Performance: } \\
\text { Evidence from a European } \\
\text { Emerging Market }\end{array}$ & $\begin{array}{l}\text { Ionascu } \\
\text { et al. }\end{array}$ & 2018 & 8 & 4.00 \\
\hline 9 & $\begin{array}{l}\text { Compliance with corporate } \\
\text { governance codes in } \\
\text { emerging economies. How } \\
\text { do Romanian listed }\end{array}$ & $\begin{array}{c}\text { Albu } \\
\text { and } \\
\text { Gîrbină }\end{array}$ & 2015 & 8 & 1.60 \\
\hline
\end{tabular}




\begin{tabular}{llccc}
\hline No. Title & Authors & $\begin{array}{c}\text { Publication } \\
\text { year }\end{array}$ & $\begin{array}{c}\text { No of } \\
\text { citations }\end{array}$ & $\begin{array}{c}\text { Average } \\
\text { citations } \\
\text { per year }\end{array}$ \\
\hline
\end{tabular}

companies comply-or-

explain?

The influence of internal corporate governance on

10 bank performance - an empirical analysis for Romania

\begin{tabular}{|c|c|c|}
\hline $\begin{array}{l}\text { Dedu } \\
\text { and } \\
\text { Chițan }\end{array}$ & 2013 & 8 \\
\hline rs cited & terature & 137 \\
\hline
\end{tabular}

Average citation of the top ten papers cited in the literature
Note. A synthesis based on the information extracted from Web of Science database

The most cited article, considering the total number of citations is Minguez-Vera and Martin (2011), published in the International Journal of Human Resource Management. The journal is a 3.04 impact factor publication, ranking in the second quartile in the management JRC category. The paper has a total of 38 citations, with a yearly average of 4.22 citations and studies the impact of management's gender diversity of the Spanish small and medium-sized companies on firm performance. Results show that the presence of women on the boards of directors has a negative impact on company's performance due to the less risky strategies, but is positively associated with less debts, more assets and larger boards.

Hațegan and Curea-Pitorac (2017), with 17 total citations, but an average of 5.67 pe year is an article published in Sustainability, an open access journal, with a 2.57 impact factor, ranking in the second quartile in the management JRC category. Testing the relationship between the charitable contributions, performance, and market value of Romanian listed companies, a positive correlation is found. Moreover, the decisions of the companies to make the charitable contributions are related to both financial and non-financial indicators.

Out of the ten top articles based on the number of total citations, eight are published in economic or multidisciplinary journals (Amfiteatru Economic; Economics and Sociology, Corporate Governance in Emerging Markets: Theories, Practices and Cases; International Journal of Human Resource Management; Journal of Business Economics and Management, and Sustainability) and two are included in the Proceedings of the International Conference.

\section{Discussion and conclusion}

This paper provides an overview of the state of research in the field of corporate governance and performance conducted by researchers from an emerging country. 
Using a Structured Literature Review (SLR), this research analyses papers published between 2010 and 2019, by Romanian authors, both in Romanian and international journals and proceedings of international conferences, indexed by the Web of Science Clarivate analytics database. While the initial search returned 340 results, after framing based on the keywords, eliminating duplicates, and restricting the availability for the full text download, a number of 114 unique articles were included in the analysis.

The results illustrate an oscillating trend, both for the recent development of the corporate governance and performance research area, and for the relevance and validation of the research based on the number of citations. Except the picks in 2014 and 2015 , the conferences proceedings include a smaller number of papers per year over the entire period as compared to the journals which concentrate more papers per year starting with 2014. The analysis of the number of authors and their affiliation returns an average number of authors of 2.36 per paper. Another aspect considered is that out of a total of 269 authors, 246 authors are affiliated to Romanian universities, publishing a total of 101 articles. Moreover, 13 articles were published in collaboration with 23 international researchers.

Additionally, a meta-analysis is used to contribute a a more comprehensive understanding of emerging countries research. A series of characteristics of the scientific papers were considered for the analysis: research theories, research methodologies, research methods, the population's characteristics, the frequency of the governance and performance keywords, and main metrics used for quantifying corporate governance and corporate performance. The results show that the most common underlying theory of Romanian studies is agency theory. Most of the Romanian authors' studies engage a quantitative methodology (78\%), focusing on corporate governance policies of the companies listed at Bucharest Stock Exchange. Approximately $43 \%$ of the papers use information collected from Romanian databases, especially the Bucharest Stock Exchange and the Romanian companies' websites. Regression analysis and descriptive statistics are the most used to analyse and debate on the relationship between corporate governance and performance. Meanwhile, the qualitative methodology is used only by $18 \%$ of the papers. Furthermore, the authors' affiliations are concentrated within three main universities in the country: Bucharest University of Economics Studies, Babeș-Boyai University of Cluj-Napoca, and Alexandru Ioan Cuza University of Iași.

The analysis continues with the study of the most used corporate governance and performance related metrics. The results show that the most common variables for corporate governance are the board's independence, the corporate governance index and the board's size, included in 42 papers. Return on Assets, Return on Equity, and Tobin's Q ratio are the first three most used metrics for the company performance, used in 77 papers. 
Another layer of analysis focuses on the quality of the articles measured through several quantitative characteristics: the number of pages, the number of references and the number of citations. The frequency analysis and the descriptive statistics show that articles with a length of 3 to 79 pages, an average number of 15.78 pages, with 40.18 references and 2.09 citations per paper, in average, were published by the Romanian authors in the area of corporate governance and performance research.

This detailed analysis may have direct implications especially in the academic environment of the European emerging countries. It contributes to providing an approach to discover under-investigating topics and methods, thus being a starting point for researchers who will further study this subject.

Future research directions may attempt broaden the sample of the papers analysed in the sense of extending it to other countries from the Eastern European region with the purpose of finding possible patterns of research in this geographical area. Moreover, future research could also investigate the tools needed by different companies in order to improve their current corporate governance mechanisms so that they have a positive impact on the performance. A difference-in-difference analysis on a sample including both emerging and developed countries characteristics may also be addressed in a future research.

\section{Acknowledgements}

We appreciate the helpful comments and the constructive suggestions on previous draft of this study presented at the International Conference Accounting and Management Information Systems (AMIS 2020), Bucharest, Romania. Special thanks are addressed to the anonymous reviewers of this research for their insightful recommendations.

\section{References}

Achim, M. V., Borlea, S. N. \& Mare, C., (2016) „Corporate Governance and Business Performance: Evidence for the Romanian Economy”, Journal of Business Economics and Management, vol. 17, no. 3:458-474

Albu, C. N. \& Girbina, M. M. (2015) „Compliance with corporate governance codes in emerging economies. How do Romanian listed companies "comply-orexplain"?", Corporate Governance: The International Journal of Business in Society, vol. 15, no. 1: 85-107

Albu, N. \& Lungu, C.I. (2012) „A profile of JAMIS publications between 2006 and 2012. Reflections on the journey towards internationalization", Accounting and Management Information Systems, vol. 11, no. 2: 141-162 
Albu, N., Lupu, I. \& Sandu, R. (2014) „Multinationals as Vectors of Corporate Governance Improvement in Emerging Economies in Eastern Europe: A Case Study", In Sabri Boubaker, Duc Khuong Nguyen (Ed.) Corporate Governance in Emerging Markets, Springer: 331-349

Al-Gamrh, B., Ku Ismail, K.N.I., Ahsan, T. \& Alquhaif, A. (2020) „Investment opportunities, corporate governance quality, and firm performance in the UAE", Journal of Accounting in Emerging Economies, vol. 10, no 2: 261-276

Arora, A. \& Bodhanwala, S. (2018) „Relationship between Corporate Governance Index and Firm Performance: Indian Evidence", Global Business Review, vol.19, no. 3: 675-689

Arora, A. (2015) „Literature Review assessing the relationship between Corporate Governance and Firm Performance, Compendium of Research Papers of National Conference on Managing tomorrow: Issues and Challenges by D.Y Patil Institute of Management Studies, vol 2, no. 1: 394-424

Azila-Gbettor, E. M., Honyenuga, B. Q., Berent-Braun, M. M. \& Kil, A. (2018) „Structural aspects of corporate governance and family firm performance: a systematic review", Journal of Family Business Management, vol. 8, no. 3: 306-330

Bansal, S. \& Thenmozhi, M. (2019) „Does Board Composition Matter to Institutional Investors?", Journal of Emerging Market Finance, vol. 18, no. 2: S238-S266

Becheikh, N., Landry, R. \& Amara, N. (2006) „Lessons from innovation empirical studies in the manufacturing sector: A systematic review of the literature from 1993-2003", Technovation, vol. 26, no: 5-6: 644-664

Bhagat, S. \& Bolton, B. (2008) „Corporate governance and firm performance”, Journal of Corporate Finance, vol. 14 no: 3: 257-273

Brown, L.D. \& Caylor, M.L. (2009) „Corporate governance and firm operating performance", Review of Quantitative Finance and Accounting, vol.32: 129-144

Caraiani, C., Lungu, C. I., Bratu, A. \& Dascălu, C. (2018) „Exploring the perspectives of integrated reporting for future research opportunities", Accounting and Management Information Systems, vol. 17, no. 4: 532-565

Chbib, I. \& Page, M. (2020) „Board Composition and Firm Performance: The Case of FTSE All Shares", IUP Journal of Corporate Governance; vol. 19, no 1: 7-27

Chijoke-Mgbame, A. M., Boateng, A. \& Chijoke O. M. (2020) „Board gender diversity, audit committee and financial performance: evidence from Nigeria”, Accounting Forum, vol. 44, no 3: 262-286

Cincalova, S. \& Hedija, V. (2020) „Firm Characteristics and Corporate Social Responsibility: The Case of Czech Transportation and Storage Industry", Sustainability, vol. 12., no. 5: 1992

Coletta, C. \& Arruda De Souza Lima, R. (2020). „Board of directors, performance and firm value in Brazilian listed state-owned enterprises", Brazilian Review of Finance, vol. 18, no 2: 1-28 
Cuervo, A. (2002) „Corporate governance mechanisms: A plea for less code of good governance and more market control", Corporate Governance: An International Review, vol. 10, no. 2: 84-93

Dedu, V. \& Chitan, G. (2013) „The Influence of Internal Corporate Governance on Bank Performance - An Empirical Analysis for Romania”, Procedia - Social and Behavioral Sciences, vol. 99: 1114-1123.

Dinca, M. S., Madaleno, M., Baba, M. C. \& Dinca, G. (2019). „Environmental Information Transparency - Evidence from Romanian Companies", Sustainability, vol. 11: 5040

E-Vahdati, S., Zulkifli, N. \& Zakaria, Z. (2019) „Corporate governance integration with sustenability: a systematic literature review", Corporate Governance Journal, vol. 19, no 2: 255-269

Fernando, G. D., Jain, S. S. \& Tripathy, A. (2020) „This cloud has a silver lining: Gender diversity, managerial ability, and firm performance", Journal of Business Research, vol. 117: 484-496.

Gherghina, Ş. C. \& Vintilă, G. (2015) „Investigating the relationship between the internal corporate governance mechanisms, CEO characteristics, and firm performance. Panel data evidence for the Bucharest Stock Exchange listed companies", Proceedings of the 10th International Conference Accounting and Management Information Systems: 761-777

Gherghina, Ş. C. \& Vintilă, G. (2016) „Exploring the Impact of Corporate Social Responsibility Policies on Firm Value: the Case of Listed Companies in Romania", Economics and Sociology, vol. 9, no. 1: 23-42

Glanzel, W. (2012) „Bibliometric methods for detecting and analysing emerging research topics". El profesional de la información, vol. 21, no. 1: 194-201

Gonzales-Bustos, J. P. \& Hernandez-Lara, A. B. (2016) „Corporate governance and innovation: a systematic literature review”, Corporate Ownership and Control Journal, vol. 13, no. 3: 33-45

Hategan, C.-D. \& Curea-Pitorac, R.-I. (2017) „Testing the Correlations between Corporate Giving, Performance and Company Value", Sustainability, vol. 9, no.7: 1210

Horobet, A., Belascu, L., Curea, S, \& Pentescu, A. (2019) „Ownership Concentration and Performance Recovery Patterns in the European Union" Sustainability, vol. 11 no 4: 953

Hussain, M. \& Hadi, A. (2019) „Corporate governance, risky business and construction industry: a divergence between Bursa and Construction Industry Development Board (CIDB) Klang Valley, Malaysia", Corporate Governance, vol. 19 no 3: 438-457.

Ienciu, I.-A., Popa, I. E. \& Ienciu, N. M. (2012) „Environmental Reporting and Good Practice of Corporate Governance: Petroleum Industry Case Study", Procedia Economics and Finance, vol. 3: 961-967.

Ionașcu, M., Ionașcu, I., Săcărin, M. \& Minu, M. (2018) „Women on Boards and Financial Performance: Evidence from a European Emerging Market", Sustainability, vol. 10, no. 5: 1644. 
Jackling, B. \& Johl, S. (2009) „Board Structure and Firm Performance: Evidence from India's Top Companies", Corporate Governance: An International Review, vol.17, no.4: 492-509

Kaur, M. \& Vij, M. (2018) „Corporate governance index and firm performance: empirical evidence from Indian banking”, Afro-Asian Journal of Finance and Accounting, vol. 8, no. 2: 190-207

Kearney, C. (2012) „Emerging markets research: Trends, issues and future directions", Emerging Markets Review, vol. 13: 159-183

Knut, M (2016) „Corporate governance effects on firm performance: A Literature Review", Regional Formation and Development Studies, vol. 20, no. 3: 84-95

Kuo, K. C., Lu, W. M. \& Dinh, T. N. (2020) „Firm performance and ownership structure: Dynamic network data envelopment analysis approach" Managerial and Decision Economics, vol. 41: 608-623

Kyere, M. \& Ausloos, M. (2020) „Corporate governance and firms financial performance in the United Kingdom”. Int J Fin Econ. 1- 15

Liu, R. (2019) „CEO Duality and Firm Performance Under Endogeneity”. SSRN Electronic Journal, https://papers.ssrn.com/sol3/papers.cfm?abstract_id $=3409469$

Lungu, C. I., Caraiani, C., Bratu, A., Dascălu, C., Turcu, D. \& Turturea, M. (2016) „Archival analysis of Corporate Social Responsibility research: The Romanian Perspective", Accounting and Management Information Systems, vol. 15 , no. 2: 341-371

Massaro, M., Dumay, J. \& Guthrie, J. (2016) „On the shoulders of giants: undertaking a structured literature review in accounting", Accounting, Auditing \& Accountability Journal, vol. 29, no. 5: 767-801

Masulis, R.W., Wang, C. \& Xie, F. (2012) „Globalizing the boardroom - The effects of foreign directors on corporate governance and firm performance", Journal of Accounting and Economics, vol. 53, no. 3: 527-554

Merendino, A. \& Melville, R. (2019) „The board of directors and firm performance: empirical evidence from listed companies", Corporate Governance, vol. 19, no. 3: 508-551

Minguez-Vera, A. \& Martin, A. (2011) „Gender and management on Spanish SMEs: an empirical analysis", The International Journal of Human Resource Management, vol. 22, no. 14: 2852-2873

Moustaghfir, K. (2008) „The dynamics of knowledge assets and their link with firm performance", Measuring Business Excellence, vol. 12, no. 2: 465-480

Nashier, T. \& Gupta, A. (2020) „Ownership Concentration and Firm Performance in India", Global Business Review, 1-18

Ng'eni, F.B., (2015) „The Corporate Governance and Firm Performance: A Review of Existing Empirical Evidence", European Journal of Business and Management, vol. 7, no. 33: 92-98

Nyaruri, F. B., Mburu, H. \& Omurwa, J. (2019) „Relationship between Corporate Governance Quality and Financial Performance of Manufacturing Firms 
Listed at the Nairobi Securities Exchange", Journal of Finance and Accounting, vol. 3, no. 2: 39-55

OECD (2015), G20/OECD Principles of Corporate Governance, OECD Publishing, Paris. http://dx.doi.org/10.1787/9789264236882-en, accessed at 19.07.2020

Oehmichen, J. (2018) „East meets west - Corporate governance in Asian emerging markets: A literature review and research agenda", International Business Review, vol. 27, no. 2: 465-480

Ouni, Z., Ben Mansour, J., \& Arfaoui, S. (2020) „Board/Executive Gender Diversity and Firm Financial Performance in Canada: The Mediating Role of Environmental, Social, and Governance (ESG) Orientation", Sustainability, vol. 12, no 20: 8386

Pham D. H. \& Pham, Q. V. (2020), „The impact of CEO duality on firm performance: Examining the life-cycle theory in Vietnam", Accounting, vol. 6: 737-742

Popescu R. \& Popescu, G. (2019) „An Exploratory Study Based on a Questionnaire Concerning Green and Sustainable Finance, Corporate Social Responsibility, and Performance: Evidence from the Romanian Business Environment. Journal of Risk and Financial Management, vol. 12, no. 4: 162

Puni, A. \& Anlesinya, A. (2020) „Corporate governance mechanisms and firm performance in a developing country", International Journal of Law and Management, vol. 62, no. 2: 147-169

Sadeh, F. \& Kacker, M. (2020) „Performance implications of using signaling and screening for expanding interfirm business networks: Evidence from franchising", Industrial Marketing Management, vol. 88: 47-58

Shah, S.Z.A., Butt, S.A. \& Saeed, M. (2011) „Ownership structure and performance of firms: Empirical evidence from an emerging market", African Journal of Business Management, vol. 5, no. 2: 515-523

Song, H.J. \& Kang, K.H. (2019), „The moderating effect of CEO duality on the relationship between geographic diversification and firm performance in the US lodging industry", International Journal of Contemporary Hospitality Management, vol. 31, no. 3: 1488-1504.

Tarraf, H. (2010) „Literature Review on Corporate Governance and the Recent Financial Crisis", SSRN Electronic Journal, https://ssrn.com/abstract= 1731044

Tranfield, D., Denyer, D. \& Smart, P. (2003) „Towards a Methodology for Developing Evidence-Informed Management Knowledge by Means of Systematic Review", British Journal of Management, vol. 14, no. 3: 207-222

Tripathi, V. (2019) „Agency theory, ownership structure and capital structure: an empirical investigation in the indian automobile industry", Asia-Pacific Management Accounting Journal, vol.14, no. 2:1-22 Available at: http://arionline.uitm.edu.my/ojs/index.php/APMAJ/article/view/766

Wijethilake, C. \& Ekanayake, A. (2019) „CEO duality and firm performance: the moderating roles of CEO informal power and board involvements", Social Responsibility Journal, vol. 16, no. 8: 1453-1474 
Zaharia, R.M., Stancu, A., Stoian, C. \& Diaconu, M. (2010) „Commercial activity's contribution to sustainable development by social responsibility actions: a vision of SMEs", Amfiteatru Economic, vol. 12, no 27: 155-167 